https://doi.org/10.52058/2708-7530-2021-12(18)-482-492

Саннікова Ольга Павлівна доктор психологічних наук, професор, Заслужений діяч науки і техники України, завідувачка кафедри загальної та диференціальної психології, Державний заклад «Південноукраїнський національний педагогічний університет імені К.Д. Ушинського», Фонтанська дор., 4, м. Одеса, 65039, e-mail: osanniland@gmail.com, https://orcid.org/00000003-3961-2103

Жень Чжун аспірант кафедри загальної та диференціальної психології, Державний заклад «Південноукраїнський національний педагогічний університет імені К.Д. Ушинського», Фонтанська дор., 4, м. Одеса, 65039, e-mail: 903843223@qq.com

\title{
ЕМОЦІЙНА ПРОНИКЛИВІСТЬ В СИСТЕМІ ФАКТОРНИХ РИС ОСОБИСТОСТІ
}

Анотація. У статті презентовано результати теоретико-емпіричного дослідження емоиійної проникливості, котра розглядається в контексті широкого спектру рис, представленого в факторній структурі особистості Раймонда Кеттелла. Теоретично розглянуто поняття емоційної проникливості як складної властивості особистості, яка забезпечує адекватне розпізнавання емоційного світу іншої людини, іiі актуальних (ситуативних, мінливих) емоцій і стійкої схильності до переживань емоцій певної модальності (емоційності як властивості особистості), котрі виявляються в різноманітних експресивних сигналах та поведінці. Емпірично досліджувалося співвідношення факторів особистості (за Р. Кеттеллом) і показників емоційної проникливості.

Встановлено значущі кореляційні зв'язки між показниками емоційної проникливості (здатність до розпізнавання емоцій) й факторами особистості (за Р. Кеттеллом). Проведено якісний аналіз даних, що дозволило вивчити факторну структуру та іiі зміст у осіб, які різняться за емоційною проникливістю. Виділено три групи осіб 3 різним рівнем емоційної проникливості. Доведено: що особам 3 високим рівнем здатності до розпізнавання емоцій крім розвиненої загальної психологічної проникливості (фактор N) притаманна сила «Я», соціальна сміливість, товариськість, екстраверсія тощо. Особам 3 низьким значенням загального показника емоційної проникливості властиві залежність від групи, соціальна боязкість, підозрілість, тривожність, i надто високий самоконтроль у проявах експресивних сигналів. Представники групи із середніми значеннями загального показника емоційної проникливості, але 3 високим значенням 
показника інтенціональності (цільова спрямованість на розпізнавання емоцій іншого) виявляють слабкість «Я», соціальна боязкість, високий самоконтроль, тривожність, підозрілість, фрустрованість, емоційна нестабільність і висока чутливість.

Виявлені фактори (риси) особистості спостерігача, які супроводжують прояви емоційної проникливості, сприяють більш точному оцінюванню емоцій іншого і властивості особистості, які гальмують цей процес.

Ключові слова: емоційна проникливість, розпізнавання, емоції, експресія, риси особистості, фактори, профілі.

Sannikova Olga Pavlivna Doctor of Psychology, professor, Honored Worker of Science and Technology of Ukraine, Head of General and Differential Psychology Department, State institution «South Ukrainian National Pedagogical University named after K. D. UshinskyFontanskaya road, 4, », Odessa, 65039, e-mail: osanniland@gmail.com, https://orcid.org/0000-0003-3961-2103

Zhen Zhong Graduate student of the Department of General and Differential Psychology, State Institution «South Ukrainian National Pedagogical University named after K. D. Ushynskyi», Fontanskaya road, 4, Odessa, 65039, e-mail: 903843223@qq.com

\section{EMOTIONAL ACUMEN IN THE SYSTEM OF PERSONALITY'S FACTOR FEATURES}

Abstract. The article presents the results of a theoretical and empirical study of emotional acumen, which is considered in the context of a wide range of traits presented in the factor structure of personality by Raymond Kettell. Theoretically, the concept of emotional acumen is considered as a complex personality trait that provides adequate recognition of the emotional world of another person, his current (situational, changing) emotions and persistent tendency to experience emotions of a certain modality (emotionality as personality traits), which are manifested in various expressive signals and behavior. The ratio of personality factors (according to R. Cattell) and indicators of emotional acumen were empirically studied.

Significant correlations were established between indicators of emotional acumen (ability to recognize emotions) and personality factors (according to R. Kettell). A qualitative analysis of the data was conducted, it allowed to study the factor structure and its content in individuals who differ in emotional acumen. There are three groups of people with different levels of emotional acumen. It is proved that people with a high level of ability to recognize emotions in addition to developed general psychological acumen (factor N) are characterized by the strength of «self», social courage, camaraderie, extraversion, and so on. Individuals with a low value of the general indicator of emotional acumen are characterized by dependence on the 
group, social cowardice, suspicion, anxiety, and too high self-control in the manifestations of expressive signals. Representatives of the group with average values of general emotional acumen, but with a high value of intentionality (target focus on recognizing the emotions of others) show weakness of «self», social cowardice, high self-control, anxiety, suspicion, frustration, emotional instability and high sensitivity.

The identified factors (traits) of the observer's personality, which accompany the manifestations of emotional acumen, contribute to a more accurate assessment of the emotions of others and those personality traits that inhibit this process.

Keywords: emotional acumen, recognition, emotions, expressiveness, personality traits, factors, profiles.

Постановка проблеми. Актуальність дослідження визначається як недостатнім вивченням процесів розпізнавання емоцій по різним невербальним, експресивним сигналам (міміка, пантоміміка, пози, жести, голос тощо), так i великою зацікавленістю психологічної практики в розумінні того, які характеристики спостерігача (психолога, психотерапевта, педагога та ін.) сприяють точному оцінюванню емоцій іншого, а які їх гальмують; наскільки адекватно сприймаються зовнішні прояви емоцій інших людей; наскільки спостерігач може бути незашореним, неупередженим тощо. Саме тому вивчення ролі особистісних, емоційних та інших характеристик спостерігача як суб'єкта діяльності, спрямованої на розпізнання емоційного світу іншої людини набуває особливого значення в сучасних умовах обмеження соціальних контактів у зв'язку з карантинними заходами.

Ця проблема торкається широкого кола питань, починаючі від емоційної й комунікативної деривації підростаючого покоління в сучасних умовах, i, навіть, до пошуку змін в проявах і оцінках емоцій в різних культурах, пошуку кроскультурних відмінностей тощо.

Аналіз останніх досліджень і публікацій. Питання розпізнавання емоцій традиційно розглядається як важливий об'єкт численних наукових пошуків у психології. В теоретико-емпіричних дослідженнях широко обговорюється проблема сприйняття, розуміння i оцінки емоційних станів, переживань людини за невербальними характеристиками спілкування, засобами експресії [5; 10; 11], за їі мімікою, пантомімікою $[1 ; 17 ; 18]$; поведінковими ознаками енергії емоцій [2], за звуковими, мовними, мімічними, пантомімічними, жестикуляційними, емоційними діями [3] тощо.

У науковій літературі для позначення процесу виявлення, яку саме емоцію випробовує інша людина, використовують терміни «упізнання», «сприйняття емоцій», «розуміння», «ідентифікація» тощо $[4 ; 5 ; 13 ; 19]$.

У цій статті використовується термін «розпізнавання» емоцій, тому що важливо не тільки позначити наявність або відсутність емоційних переживань, але й спробувати визначити, яку саме емоцію випробовує в цей момент людина, 
за якою ведеться спостереження.

Такою інтегральною властивістю, яка забезпечує успішність розпізнавання емоцій, є емоційна проникливість [12]. Емоційна проникливість розглядається нами як один із видів психологічної проникливості, яка вивчалася в роботах О. П. Санникової та О. Киселевої [14]. Видатний український психолог Е. Л. Носенко, вивчаючі ці роботи, назвала психологічну проникливість «підгрунтям щодо основної функції емоційного інтелекту - стресозахисної та адаптивної» [9]. Емоційна проникливість трактується як складна властивість особистості, яка на основі сигналів експресії та поведінки, забезпечує адекватне розпізнавання емоційного світу іншої людини, їі актуальних (ситуативних, мінливих) емоцій і стійкої схильності до переживань емоцій певної модальності, тобто, емоційності як властивості особистості.

Цікаво те, що структура емоційного інтелекту містить показник, який спрямований на діагностику саме здібностей до розпізнавання емоцій іншої людини. Так, субшкала МП - розуміння чужих емоцій - відбиває здатність спостерігача розуміти емоційний стан людини на основі зовнішніх проявів, на основі експресії та поведінки (міміка, жестикуляція, звучання, тембр, сила голосу тощо) i/або інтуїтивно виявляти чуйність до внутрішніх станів інших людей $[6 ; 7]$.

Відомо, що на сприйняття емоцій впливає велика кількість різних факторів, які можна розділити на ситуаційні (об’єктивні) i пов'язані iз психологічними особливостями спостерігача (суб'єктивні). Серед останніх можна виділити й актуальні стани спостерігача які проявляються в емоційній, вольовий, інтелектуальної сферах у момент сприйняття й розпізнавання емоцій, і стійкі властивості особистості, які також можуть впливати на результати спостереження.

Крім того, важливо відзначити, що сприйняття й розпізнавання емоцій - це процес не простого відтворення інформації, а активне конструювання образа, при якому виникає єдність внутрішніх (диспозиційних) характеристик особистості спостерігача й особливої форми відбиття в його свідомості емоційного світу іншої людину. Саме тому емоційні характеристики й властивості особистості самого спостерігача відіграють далеко не другорядну роль у розпізнаванні емоцій іншого.

Отже, мета цієї статті - презентувати результати дослідження тих властивостей особистості, які зв'язані зі здатністю розпізнавати емоційні переживання іншого. Причому, здійснюється пошук рис, які підтримують, сприяють розпізнаванню емоцій за експресивними сигналам, i тих якостей спостерігача, які гальмують, блокують цей процес.

Конкретно, ми вивчали особливості емоційної проникливості (здатність до розпізнавання емоцій іншого) у співвідношенні з характеристиками факторної структури особистості (за факторною концепцією Раймонда Кеттелла) [8; 15; 16$]$.

Задля досягнення мети слід вирішити такі завдання: 1) обрати адекватні 
цілям психодіагностичні методики, скласти вибірку осіб, які будуть підлягати психологічному обстеженню; 2) із вибірки обстежених виділити групи осіб 3 різним рівнем емоційної проникливості; 3) побудувати усереднені профілі факторної структури особистості, проаналізувати кожний з них та порівняти їх між собою задля пошуку специфіки кожного.

Виклад основного матеріалу. Для діагностики широкого спектру рис особистості, що співвідносяться 3 показниками емоційної проникливості, ми обрали Багатофакторний особистісний опитувальник 16PF Р. Кеттелла (Sixteen Personaflity Factor Questionnaire, 16PF) [8; 15].

Емоційну проникливість вивчали за допомогою процедури «Розміщення себе на шкалах емоційної проникливості». Ця процедура $є$ модифікацією методики Т. Дембо і С. Рубінштей, що вивчає особливості самооцінки. Різні модифікації цієї методики досить представлено в літературі. Крім того, враховувались результати субшкали МП - розуміння чужих емоцій за методикою діагностики емоційного інтелекту [6; 7]. Співставлення результатів за шкалою МП з результатами загального показника емоційної проникливості було підставою для групування обстежених за рівнем виразу загального показника цієї властивості.

В емпіричному дослідженні брали участь 110 осіб у віці від 20 до 30 років - студентів Південноукраїнського національного педагогічного університету імені К.Д. Ушинського.

Слід зазначити, що попередньо був проведений кореляційний аналіз між усіма показниками, що вивчаються, який показав наявність значущих зв’язків, i додатних, і від'ємних. Ці результати свідчать про доречність переходу до якісного аналізу, що і $є$ метою цієї частини роботи. Якісний аналіз даних проводився методами асів i профілів, що дозволило вивчити факторну структуру особистості (в контексті концепції Р. Кеттелла) та їі зміст у осіб, які різняться за емоційною проникливістю.

Із усієї вибірки за допомогою методу асів [10] обрано 3 групи осіб. Першу групу (EPmax) склали особи з високими значеннями загального показника схильних до розпізнавання емоційного світу іншого (емоційної проникливості); другу групу (EPmin) представляють особи, які мають найменше значення загального показника емоційної проникливості, тобто ті, які не схильні до сприйняття емоційних сигналів іншої людини; третю групу (ЕРх) склали особи, які мають середні значення загального показника емоційної проникливості, але, за рахунок великих значень по інтенціональності і низьких - за рахунок формально-динамічних показників.

Отже, на рис. 1 представлені факторні профілі кожної із зазначених груп. На осі ОХ традиційно розташовані всі фактори особистості (i первинні, i вторинні), що діагностовано методикою 16 PF; на осі OY - стандартні оцінки за кожним фактором, максимум дорівнює 10 стенам, мінімум - 1 стен. Середня лінія ряду проходить через позначку в 5,5 стена. 
Значення кожного фактора, що знаходяться вище середньої лінії ряду, тяжіють до додатного полюсу, а ті, що розташовані нижче середньої лінії ряду - відповідно, до від'ємного полюсу. Всі значення факторів за методикою 16 PF розподіляються на чотири рівних квартіля. Для оцінки рівня розвитку факторів, для нас цікавими й значущими є перший (від 1 до 3,25 стена) і четвертий (від 7,25 до 10 стенів) квартілі розподілу, або тенденції до цих значень.

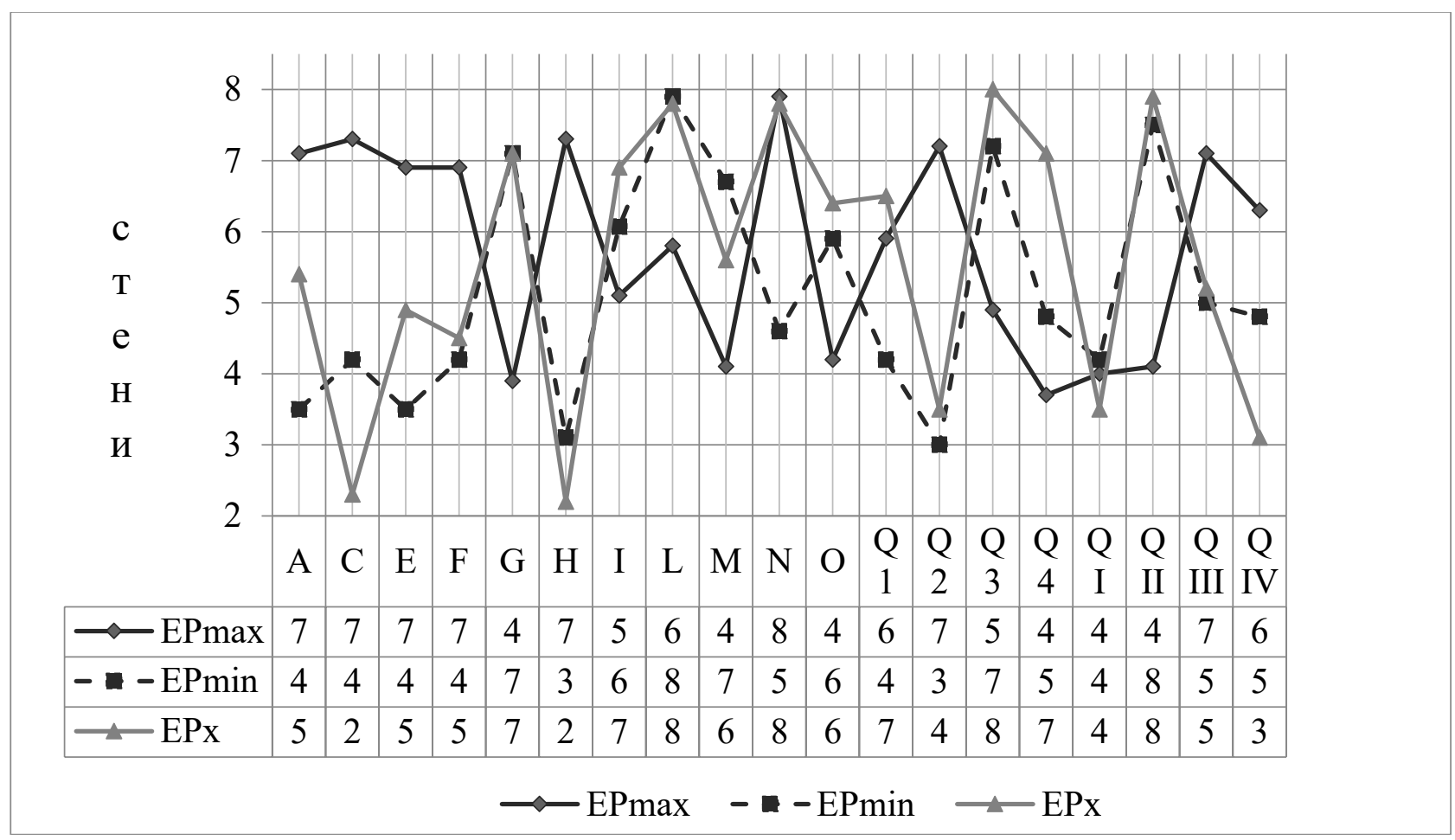

Puc. 1. Профілі факторної структури особистості (за методикою 16-PF) трьох груп осіб: перша група EPmax $(N=12) ;$ друга - Epmin $(N=10) ;$ третя груnа $-\operatorname{EPx}(N=13)$.

Примітка. Тут і далі: умовні позначення біполярних факторів особистості (першими надано додатні полюси факторів): А (афектотимія - сизотимія); С (сила «Я» - слабкість «Я»); Е (домінантність - покірність); F (безпечність заклопотаність); G (сила «Над-Я» - слабкість «Над-Я»); Н (соціальна сміливість - соціальна боязкість); I (висока - низька чутливість); L (підозрілість - довірливість); М (мрійливість - практичність); N (проникливість - наївність); O (схильність до відчуття провини - самовпевненість); Q1 (радикалізм консерватизм); Q2 (самодостатність - залежність від групи); Q3 (високий самоконтроль - низький самоконтроль); Q4 (фрустрованість нефрустрованість); QI (екстраверсія - інтроверсія); QII (тривожність - емоційна стабільність); QIII (кортикальна жвавість - сенситивність); QIV (незалежність покірність).

Розглянемо профіль кожної групи обстежених для встановлення їх специфіки (якісно-кількісне поєднання показників), потім порівняємо профілі

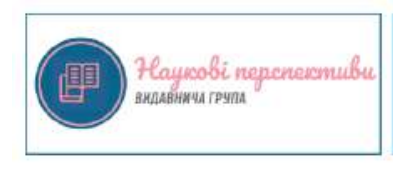


між собою задля пошуку відмінностей між ними. Ранжування факторів за методикою 16 PF здійснюється за найбільшим відхиленням значень від середньої лінії ряду у представників кожної групи. Результати представлено в табл. 1. Аналіз табл.1 дозволяє розкрити зміст факторів у порядку їх ранжування за ступенем виразу кожного i на основі інтерпретації факторів автором методики [8], описати рисі особистості, які супроводжують прояви емоційного інтелекту в залежності від його розвитку.

Таблиияя 1

Ранжування факторів особистості в профілях кожної групи (за методикою 16-РF Р. Кеттелла)

\begin{tabular}{|c|c|c|c|}
\hline \multirow[t]{2}{*}{ Ранг } & \multicolumn{3}{|c|}{ Групи осіб, з різними проявами емоційної проникливості } \\
\hline & група EPmax & група EPmin & група EPx \\
\hline 1 & $\mathrm{~N}+$ (проникливість) & $\begin{array}{c}\text { Q2- (залежність від } \\
\text { групи) }\end{array}$ & C- (слабкість «Я») \\
\hline 2 & \multirow{2}{*}{$\begin{array}{c}\text { C+ (сила «Я») } \\
\text { Н+ (соціальна } \\
\text { сміливість) }\end{array}$} & $\begin{array}{c}\text { H- (соціальна } \\
\text { боязкість) }\end{array}$ & $\begin{array}{c}\text { H- (соціальна } \\
\text { боязкість) }\end{array}$ \\
\hline 3 & & L+ (підозрілість) & $\begin{array}{l}\text { Q3+ (високий } \\
\text { самоконтроль) }\end{array}$ \\
\hline 4. & \multirow{2}{*}{$\begin{array}{c}\text { A+ (афектотимія) } \\
\text { QI+ (екстраверсія) } \\
\text { QIII+ (кортикальна } \\
\text { жвавість) }\end{array}$} & QII+ (тривожність) & QII+ (тривожність) \\
\hline 5 & & $\begin{array}{l}\text { Q3+ (високий } \\
\text { самоконтроль) }\end{array}$ & L+ (підозрілість) \\
\hline
\end{tabular}

Отже, представникам групи ЕРmax властиві прояв и проникливості стосовно навколишніх, честолюбство, обережність, вишуканість, уміння поводитися в суспільстві, точний розум, емоційна стриманість, вміння поводитися штучно i навіть виявляти артистичність у поведінці (N+). Їм властива емоційна стійкість, незалежність від невротичних симптомів, сталість інтересів, наполегливість, завзятість, реалістичність у відношенні до життя, спокій $(\mathrm{C}+)$. Вони соціально сміливі, товариські, відкриті (QI+), довірливі, часом безтурботні (A+), пожвавлюються в присутності осіб протилежної статі, чуйні, мають широкі інтереси, дружелюбні й люблять бути на очах (H+); безтурботні, кмітливі, готові вирішувати життєві проблеми (QIII+).

Що стосується представників групи осіб, які виявляють низькі значення загального показника емоційної проникливості (група EPmin) то їм властиві досить висока залежність від групи, несамостійність, прихильність до групи. Ці люди у своїй поведінці орієнтуються на групову думку, потребують постійної опори, підтримки навколишніх, схваленні власного вибору й поведінки (Q2). Такі особи виявляють соціальну боязкість, стриманість, соромливість, зніяковілість у присутності осіб протилежної статі. Інтереси у них обмежені, вони відчувають страх до життя (Н-). Крім цього, представники цієї групи 
характеризуються підозрілістю, фіксацією на невдачах, ревнощами тощо (L+), тривожністю, схильністю до переживання суму, печалі (QII+), високим самоконтролем поведінки і бажань. Ці особи чутливі до соціального схвалення, усвідомлюють соціальні вимоги й намагаються їх акуратно виконувати, опікуються про враження, яке роблять своєю поведінкою, опікуються своєю репутацією $(\mathrm{Q} 3+)$. Представники третьої групи осіб (ЕРх), тобто групи із середніми значеннями загального показника емоційної проникливості та 3 високим значенням показника інтенціональності (цільова спрямованість на розпізнавання емоцій іншого) виявляють певну схожість 3 другою групою.

При порівнянні груп обстежених між собою (між однойменними показниками профілів трьох груп обстежених) за значеннями t-критерію Ст'юдента, встановлено, що розбіжності спостерігаються більшою мірою між профілем першої групи і двох інших: другою і третьою. Якщо характеризувати другу i третю групи, то за змістом представники обох груп виявляють схожі риси особистості: соціальну боязкість (H-), високий самоконтроль $(\mathrm{Q} 3+)$, тривожність (QII)+, підозрілість (L+). Проте, слід зазначити, що основна відмінність між цими групами виявилася у тому, що групі ЕРх, тобто, із середніми значеннями психологічної проникливості, притаманна слабкість «Я» (C-), а групі EPmin - залежність від групи (Q2-).

\section{Висновки:}

1. У досліджені вивчаються особливості емоичійної проникливості, котра розглядається в контексті широкого спектру рис, представленого в факторній структурі особистості Раймонда Кеттелла. Емоційна проникливість розглядається як властивість особистості, яка на основі сигналів експресії та поведінки, забезпечує більш точне розпізнавання емоційного світу іншої людини, їі актуальних (ситуативних, мінливих) емоцій і стійкої схильності до переживань емоцій певної модальності, тобто, емоційності як властивості особистості.

2. Емпіричне дослідження спрямоване на пошук співвідношення факторів особистості (за Р. Кеттеллом) і показників емоційної проникливості. Якісний аналіз даних методом асів і профілів дозволив вивчити факторну структуру особистості (в контексті концепції Р. Кеттелла) та їі зміст у осіб, які різняться за емоційною проникливістю.

3. Встановлено, що особам з високим рівнем здатності до розпізнавання емоцій крім розвиненої загальної психологічної проникливості притаманна сила «Я», соціальна сміливість, товариськість, екстраверсія тощо. Особам 3 низьким значенням загального показника емоційної проникливості властиві залежність від групи, соціальна боязкість, підозрілість, тривожність, високий самоконтроль. Представники групи із середніми значеннями загального показника емоційної проникливості та 3 високим значенням показника інтенціональності (цільова спрямованість на розпізнавання емоцій іншого) виявляють слабкість «Я», соціальну боязкість, високий самоконтроль,

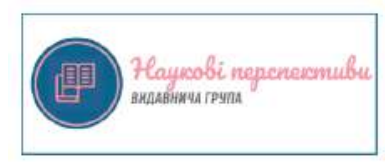


тривожність, підозрілість, фрустрованість, емоційну нестабільність і високу чутливість.

Виявлені фактори (риси) особистості спостерігача, які супроводжують прояви емоційної проникливості, сприяють більш точному оцінюванню емоцій іншого (виявляється у представників першої групи), і властивості особистості, які гальмують цей процес (у представників другої і третьої групи з низькими значеннями показника емоційної проникливості).

\section{Лimepamypa:}

1. Барабанщиков В. А. Восприятие выражений лица. М. : Изд-во Институт психологии PAH», 2009. $448 \mathrm{c}$.

2. Бойко В. В. Энергия эмоций. 2-е изд. доп. и перераб. СПб. : Питер, 2004. 474 с.

3. Варій М. Й. Загальна психологія : Навчальний посібник. 2-ге видан., випр. і доп. К. : Центр учбової літератури, 2007. 968 с.

4. Кириленко Т. С. Психологія: емоиійна сфера особистості: Навч. посібник. К. : Либідь, 2007. 256 с.

5. Лабунская В.А., Менджерицкая Ю.А., Бреус Е. Д. Психология затрудненного общения: Теория. Методы. Диагностика. Коррекияи: Учебное пособие для студ. Высш. Учеб. Заведений. М. : Издат. центр «Академия», 2001. 288 с.

6. Люсин Д. В. Новая методика для измерения эмоционального интеллекта : опросник ЭмИн. Психологическая диагностика. 2006. № 4, 3-22.

7. Люсин Д. В., Марютина О. О., Степанова А. С. Структура эмоционального интеллекта и связь его компонентов с индивидуальными особенностями: эмпирический анализ. Социальный интеллект: Теория, измерение, исследования / Под ред. Д. В. Люсина, Д. В. Ушакова. М.: Институт психологии РАН, 2004. С. 128-140.

8. Мельников В. М., Ямпольский Л. Т. (1985). Введение в экспериментальную психологию личности: Учеб. пособие для слушателей ИПК преподавателей пед. дисциплин ун-тов и пед. ин-тов. М. : Просвещение, 1985. 319 с.

9. Носенко Е. Л., Коврига Н. В. Емоційний інтелект : концептуалізаџія феномену, основні функиї. [Монографія]. К. : Вища шк., 2003. 126 с.

10. Санникова О. П. Эмоциональность в структуре личности : Монография. Одесса : Хopc, 1995. $334 \mathrm{c.}$

11. Саннікова О. П., Санникова А.О. Сиенічні бар’єри: диференціально-психологічний nidxid: Монографія. Одеса : ВМВ, 2014. 238 с.

12. Саннікова О.П. Психологічна проникливість як інструмент осягнення сутності іншої людини. Проблеми сучасної психології: збірник наукових пращь Державного вищого навчального закладу «Запорізький національний університет» та Інституту психології імені Г. С. Костюка НАПН України / За ред. С. Д. Максименка, Н. Ф. Шевченко, М. Г. Ткалич. Запоріжжя : ЗНУ, 2017. № 2 (10). С. 19-23.

13. Саннікова О. П. Макроструктура особистості: психологічний опис. Наука і освіта. Тематичний спеивипуск «Психологія особистості: теорія, досвід, практика». 2013. № 7/CXVII. C. 7-12.

14. Саннікова О. П., Кисельова О.А. Науково-методичний твір «Тест-опросник психологической проницательности». Свідотство про реєстрацію авторського права на твір № 8831. Мін. освіт. і науки України. Заяв. № 8648 від 01.10.2003. Опубл. 24.11.2003. 27 с.

15. Cattell R. B. Personality and Motivation. Structure and Measurement. N.Y., 1957. Ch. 46. P. 85-254.

16. Cattell R. B. The scientific analysis of personality. Harmondsworth, 1967. 400 p.

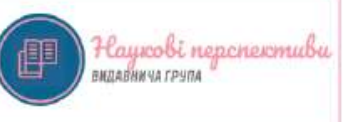


17. Ekman P., Friesen W. V. Unmasking the Face: a Guide to Recognizing Emotions from Facial Expressions. Englewood Cliffs, N.J.: Prentice-Hall,, 1975. 211 p.

18. Ekman P., Friesen W., Tomkins S. Facial affect scoring technigues: a first validity studi. Semiotika. 1971. Vol. 3. P. 37-58.

19. Scherer K. R. How emotion is expressed in speech and singing. Proc. ICPhS, Stockholm. 1995. Vol. 3. P. 90-96.

\section{References:}

1. Barabanshchikov, V.A. (2009). Vospriiatie vyrazhenii litsa [Perception of facial expressions]. M. : Izd-vo Institut psikhologii RAN [in Russian].

2. Boiko, V. V. (2004). Energiia emotsii [The energy of emotions] (2 ${ }^{\text {nd }} .$, ed., rev.). SPb. : Piter [in Russian].

3. Varii, M. Y. (2007). Zahalna psykholohiia [General psychology] (2 ${ }^{\text {nd }}$, ed., rev.). K. : Tsentr uchbovoi literatury [in Ukrainian].

4. Kyrylenko, T. S. (2007). Psykholohiia: emotsiina sfera osobystosti [Psychology: the emotional sphere of personality]. K. : Lybid [in Ukrainian].

5. Labunskaia, V. A., Mendzheritskaia, I. A. \& Breus, E. D. (2001). Psikhologiia zatrudnennogo obshcheniia: Teoriia. Metody. Diagnostika. Korrektsiia [Psychology of difficult communication: Theory. Methods Diagnostics. Correction]. M. : Izdatelskii Tsentr «Akademiia» [in Russian].

6. Ljusin, D. V. (2006). Novaja metodika dlja izmerenija jemociona l'nogo intellekta : oprosnik JemIn [A new technique for measuring emotional intelligence: the Emin questionnaire]. Psihologicheskaja diagnostika - Psychological diagnostics. \# 4, 3-22 [in Russian].

7. Ljusin, D. V., Marjutina, O. O. \& Stepanova, A. S. (2004). Struktura jemocional'nogo intellekta i svjaz' ego komponentov s individual'nymi osobennostjami: jempiricheskij analiz [The structure of emotional intelligence and the relationship of its components with individual characteristics: an empirical analysis]. Social'nyj intellekt: Teorija, izmerenie, issledovanija / Pod red. D. V. Ljusina, D. V. Ushakova. M. : Institut psihologii RAN [in Russian].

8. Melnikov, V. M. \& Yampolsky, L. T. (1985). Vvedenye v eksperymentalnuiu psykholohyiu lychnosty [Introduction to experimental personality psychology]. M. Prosveshhenye [in Russian].

9. Nosenko, E. L. \& Kovryha, N. V. (2003). Emotsiinyi intelekt: kontseptualizatsiia fenomenu, osnovni funktsii [Emotional intelligence: conceptualization of the phenomenon, basic functions]. Kyiv: Vyshcha shk. [in Ukrainian].

10. Sannikova, O.P. (1995). Emotsionalnost v strukture lichnosti [Emotionality in the structure of personality]. Odessa : Khors [in Russian].

11. Sannikova, O. P. \& Sannikova A. O. (2014). Stsenichni bariery: dyferentsialno-psykholohichnyi pidkhid [Stage barriers: differential-psychological approach]. Odesa : VMV [in Ukrainian].

12. Sannikova, O.P. (2017). Psykholohichna pronyklyvist yak instrument osiahnennia sutnosti inshoi liudyny [Psychological insight as a tool for understanding the essence of another person]. Problemy suchasnoi psykholohii: zbirnyk naukovykh prats Derzhavnoho vyshchoho navchalnoho zakladu «Zaporizkyi natsionalnyi universytet» ta Instytutu psykholohii imeni H. S. Kostiuka NAPN Ukrainy. № 2 (10), 19-23 [in Ukrainian].

13. Sannikova, O.P. (2013). Makrostruktura osobystosti: psykholohichnyi opys [The macrostructure of the Personality: psychological description]. Nauka i osvita. Tematychnyy spetsvypusk «Psykholohiya osobystosti: teoriya, dosvid, praktyka». № 7/SKHVII, 7-12 [in Ukrainian].

14. Sannikova, O. P. \& Kyselova, O. A. (2003). Naukovo-metodychnyi tvir "Test-oprosnyk psykholohycheskoi pronytsatelnosty» [Scientific and methodical work "Test-questionnaire of psychological insight»]. Svidotstvo pro reiestratsiiu avtorskoho prava na tvir № 8831. Min. osvit. i nauky Ukrainy. Zaiav. № 8648 vid 01.10.2003. Opubl. 24.11.2003 [in Ukrainian].

15. Cattell, R. B. (1957). Personality and Motivation. Structure and Measurement. N.Y., Ch. 4-6, 85-254.

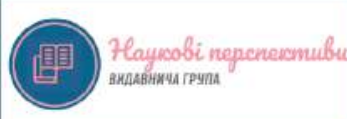


16. Cattell, R. B. (1967). The scientific analysis of personality. Harmondsworth. $400 \mathrm{p}$.

17. Ekman, P. \& Friesen, W. V. (1975). Unmasking the Face: a Guide to Recognizing Emotions from Facial Expressions. Englewood Cliffs, N.J.: Prentice-Hall. 211 p.

18. Ekman, P., Friesen, W. \& Tomkins, S. (1971). Facial affect scoring technigues: a first validity studi. Semiotika. Vol. 3. P. 37-58.

19. Scherer, K. R. (1995). How emotion is expressed in speech and singing. Proc. ICPhS, Stockholm. Vol. 3, 90-96. 